\title{
English in the European Union after Brexit: Inclusion effects of a language without an owner
}

Ushma Chauhan Jacobsen (ucj@cc.au.dk)

Aarhus University, Denmark

It was not only Britain that officially entered the European Economic Community in 1973 but also the English language. Although English is only one of 24 official languages that figures in the multilingual kaleidoscope that characterizes the $\mathrm{EU}$, its position of privilege cannot be overlooked. Not only does it sit comfortably with German and French as one of three EU procedural languages, it is widely acknowledged as the lingua franca par excellence required for the negotiation of international relations, the articulation and promotion of nation-specific agendas, and the professional career advancement of EU civil servants. It is also the working language of the European Central Bank. The Brexit referendum result on $24^{\text {th }}$ June 2016 did not only raise concerns about the implications of Britain's exit from the EU within wide spanning domains of trade and commerce, environment, social justice, or migration and security, but also about which language(s) these issues were to be discussed, debated, and contested in.

Pungent statements on the future role of English from MEPs and other commentators appeared on different media platforms soon after the declaration of the referendum result. A senior MEP stated, 'If we don't have the UK, we don't have English'. Another tweeted, 'English cannot be the third working language of the European parliament' ${ }^{\text {'ii }}$. And another hashtag post stated, 'The English language has no more legitimacy in Brussels' iii. Such troubling headlines provoked a series of reactions that voiced the imaginings of English in a post-Brexit age.

But why the fuss? Although there is a well-established understanding that nations and their languages have been closely intertwined in the history of European nation building and indeed in all postcolonial and present-day nation building efforts too - the history of the critical position that English occupies in the contemporary EU is unrelated to the history of using national languages as symbolic ammunition to build nations. After all, French, German, Italian and Dutch were all important languages in the the European Coal and Steel Community (ECSC) established in 1951. French held a position of privilege then as European institutions operated from French-speaking cities such as Brussels, Luxembourg and Strasbourg.

The entry of Britain into the EU could certainly suggest the entry of an imperialistic code for communication into the EU's official language regime. No one can turn a blind eye to, nor forget, the role that English played to establish and maintain asymmetries of power in Britain's settler and exploitative colonies. Yet to accord Britain the sole responsibility in accounting for the penetration of English into national educational systems all over the world, including within Hispanophone, Francophone and Lusophone nations, would be an error. The deep spread of English within the domains of global media, global business, global finance and global entertainment are outcomes of the emergence of the US as an influential global structuring agent after the Second World War. And it so happened that the US also spoke the same language that Britain spoke. In David Crystal's words, 'the language behind the US dollar was Englishiv ${ }^{\text {iv }}$. 
These two faces of English - one British, one not-so-British - inform the fuss about English after Brexit. The first face of English articulates itself in 'official', top-down and symbolic terms that is critical to the discussion of the recognition of cultural diversity and uniqueness of the people and nations of the EU. It supports the notion of linguistic rights of individual nation member states and is ideologically motivated. Why else should Ireland notify Gaelic or Malta notify Maltese into the EU's language regulation when their MEPs and civil servants use English to conduct their business? The other face of English articulates another dimension that is characterized by bottom-up and pragmatic approaches that is free of native-speaker complexes that users of English as a foreign language often encounter. This face privileges the intrinsic virtues of any language that performs as a lingua franca to enable contact and communication; and it privileges the virtues of any language that has the ability to include many speakers without creating language hierarchies between them. As a MEP from Sweden stated, 'keeping English now could actually make communications in the EU a bit fairer, since most of those speaking it would be using a foreign language.'v

The Wall Street Journal stated that Brexit would 'erode the status of the English language in EU institutions ${ }^{\prime v i}$ but this did not necessarily imply that English would not continue as a 'working' language. The Irish Times was quick to respond that although Gaelic would remain the official language, English would remain the working language of Ireland ${ }^{\text {vii }}$. The risks attached to imagining the withdrawal of English as a working language from the EU is reckless. Firstly, the inclusion of one compulsory foreign language has been part of European national education frameworks - with the exception of Britain and Ireland since the mid 1970s. The general monolingualism mindset of Anglophone nations stands in contrast to the general multilingual ambitions and practices of other European member states. Not only is English seen as important in relation to the EU, but also far beyond.

The morphing of English - of sounds, words, grammar, idiomatic expressions - during the course of the last forty years shows how a language changes. Many of these changes are captured in complex notions of Englishes such Euro-English, International English or Lingua Franca English. Despite hefty claims and counter claims made by scholars and practitioners on whether such varieties of English exist or not, the fact that non-native speakers of English outnumber native speakers is undeniable. Thus, the drop in native speakers of English in the EU that follows Brexit may appear dramatic - but only if we retain a view of English as the property of Britain - which many would agree it ceased to be a long time ago. The reconstitution of English as a language for many different peoples and communities has already matured since the late 1990s when Suresh Canagarajah wrote of the 'resistance perspective' through which English users 'may find ways to negotiate, alter and oppose political structures, and reconstruct their languages, cultures and identities to their advantage. The intention is not to reject English, but to reconstitute it in more inclusive, ethical, and democratic terms ${ }^{\prime \text { viii }}$.

Secondly, the EU is described as the largest translation organization in the world ${ }^{\text {ix }}$ involving intricate arrangements of specialized professionals working with translation and interpretation processes in 24 official languages. However, in this complex and costly practice, English is a vital relay language. The EU's Directorate-General for Translation regularly synthesizes and disseminates glossaries that list neologisms, terminologies and jargon associated with Eurospeak. The publication of numerous style guides help establish common forms of English usage in EU domain specific contexts ${ }^{x}$. The displacement of English would require substantial rearrangements and recruitment in the translation machine that accompany the daily practice of EU civil servants. 
Thirdly, language is both a marker of identity as well as a means of communication. Those interested in promoting the ideology of the former will always face the pragmatic presence of the latter. On $28^{\text {th }}$ June 2016, the New York Times reported that despite Brexit, 'likely very little' would change in relation to the use of English in the EU. On the same day, Forbes magazine ran an article insisting that English was the language of business, and the use of English in the EU was 'a market driven outcomexi. Despite this excessively simplified and instrumental view of language, it also points to the everyday pragmatism that top-down impositions of language regimes often encounter. In practice, professionals use the language that is required to get the work done and to achieve results. The EU cannot be an exception.

Clocks cannot be rewound. English is far too entrenched into the global communicative pipelines of politics, finance and culture. English will certainly remain in the EU, thrive and be reimagined. But this does not mean that the privileged role it occupies in the EU should escape critical scrutiny. As Julia Kristeva evocatively writes in her essay on Homo Europaeus $^{\mathrm{xii}}$, the ambition is perhaps not to simply reduce Europe's plurilinguistic space to the bilingualism of 'global' English. Instead there is still work to be done in encouraging the emergence of polyphonic subjects and polyglot citizens of a plurinational Europe.

\footnotetext{
' Goulard, H. (2016, June 27). English will not be an official EU language after Brexit, says senior MEP. Politico. Retrieved from http://www.politico.eu

ii Linn, A. (2016, July 11). English is and will be the lingua franca of Europe in spite of Brexit. Quartz. Retrieved from http://www.qz.com

iii Clavel, G. (2016, June 25). After Brexit, French politicians want English language out of EU too. Retrieved from http://www.huffingtonpost.com

${ }^{\text {iv }}$ Crystal, D. (2003). English as a Global Language. Cambridge: Cambridge University Press

'Steinhauser, G. (2016, June 27). English loses currency as Europe's lingua franca after Brexit vote. The Wall Street Journal. Retrieved from http://www.wsj.com

${ }^{v i}$ Steinhauser, G. (2016, June 27). English loses currency as Europe's lingua franca after Brexit vote. The Wall Street Journal. Retrieved from http://www.wsj.com

vii Carey, D. (2016, July 18). English will remain the working language of the EU after Brexit. The Irish Times. Retrieved from http://www.irishtimes.com

viii Canagarajah, S. (1999). Resisting linguistic imperialism in English teaching. Oxford: Oxford University Press.

ix Brexit: The demise of English as an international language? (2016) Pangeanic. Retrieved from http://www.pangeanic.com

${ }^{x}$ Examples may be found at http://ec.europa.eu/translation/english/guidelines/en_guidelines_en.htm

${ }^{\mathrm{xi}}$ Worstall, T. (2016, June 28). Brexit effects: EU to try to stop using English, but it doesn't work that way. Forbes. Retrieved from http://www.forbes.com

xii Kristeva J. (2016). Homo Europaeus: Does a European culture exist? Open Mind. Retrieved from http://www.bbvaopenmind.com
} 